\title{
How Betula ermanii Maintains a Positive Carbon Balance at the Individual Leaf Level at High Elevations
}

\author{
Koichi Takahashi ${ }^{1,2}{ }^{*}$, Sohei Otsubo ${ }^{1}$ \\ ${ }^{1}$ Department of Biology, Faculty of Science, Shinshu University, Matsumoto, Japan \\ ${ }^{2}$ Institute of Mountain Science, Shinshu University, Matsumoto, Japan \\ Email: *koichit@shinshu-u.ac.jp
}

How to cite this paper: Takahashi, K. and Otsubo, S. (2017) How Betula ermanii Maintains a Positive Carbon Balance at the Individual Leaf Level at High Elevations. American Journal of Plant Sciences, 8, 482494.

https://doi.org/10.4236/ajps.2017.83033

Received: January 23, 2017

Accepted: February 12, 2017

Published: February 15, 2017

Copyright (๑) 2017 by authors and Scientific Research Publishing Inc. This work is licensed under the Creative Commons Attribution International License (CC BY 4.0).

http://creativecommons.org/licenses/by/4.0/

\begin{abstract}
Generally, plant species with shorter leaf longevity maintain a positive carbon balance by decreasing leaf mass per area (LMA) and increasing photosynthesis. However, plants at high elevations need to increase LMA against environmental stresses. Therefore, plants need to increase both LMA and photosynthesis at high elevations. To examine how deciduous plants maintain a positive carbon balance at high elevations, photosynthesis and related leaf traits for deciduous broad-leaved tree Betula ermanii were measured at three elevations. LMA was greater at middle and high elevations than at low elevation. Leaf $\delta^{13} \mathrm{C}$ was greater at higher elevations, and positively correlated with LMA, indicating greater long-term deficiency of $\mathrm{CO}_{2}$ in leaves at higher elevations. However, the $C_{i} / C_{a}$ ratio at photosynthetic measurement was not low at high elevations. Nitrogen content per leaf mass and stomatal conductance were greater at higher elevations. Photosynthetic rates and photosynthetic nitrogen use efficiency (PNUE) did not differ among the three elevations. Photosynthetic rate showed a strong positive correlation with stomatal conductance on a leaf area basis $\left(R^{2}=0.83, P<0.001\right)$. Therefore, this study suggests B. ermanii compensates the deficiency of $\mathrm{CO}_{2}$ in leaves at high elevation by increasing stomatal conductance, and maintains photosynthesis and PNUE at high elevation as much as at low elevation.
\end{abstract}

\section{Keywords}

Leaf Mass per Area, Leaf Nitrogen, Photosynthesis, Stable Carbon Isotope Ratio, Stomatal Conductance

\section{Introduction}

Leaf longevity of deciduous plant species decreases at higher elevations because 
the length of growing seasons for plants is shorter [1] [2]. It is often reported that leaf longevity positively and negatively correlates with leaf mass per area (LMA) and assimilative capacity (i.e., photosynthetic rate at light saturation), respectively [3] [4] [5]. The photosynthetic rate is expected to be greater and LMA smaller for deciduous plant species at higher elevations because leaf longevity is shorter at higher elevations. However, environmental stresses, such as strong wind, low temperature and UV-B, also increase at high elevations [6]. Plants need to increase the mechanical stiffness of leaves (i.e., LMA) to tolerate these stresses [6] [7]. Woodward [8] showed that LMA of grass plants increases at higher elevations, and stated that these plants adapt to strong wind and low temperature at high elevations by increasing mechanical stiffness. Thus, plants need to make tough leaves with high LMA at higher elevations, even though their leaf longevity is short. Namely, plants must acquire both high LMA and high photosynthetic rates at high elevations. Many studies have been done on elevational changes of photosynthetic characteristics. It is often reported that the photosynthetic rate of deciduous broad-leaved tree species increases at high elevations [9] [10]. However, whether deciduous plant species increase both LMA and photosynthesis at high elevations and how a positive carbon balance is maintained there have not been clarified.

Although plants tend to preferentially use ${ }^{12} \mathrm{CO}_{2}$ rather than isotopically heavier ${ }^{13} \mathrm{CO}_{2}$ during carbon assimilation, they have to assimilate more ${ }^{13} \mathrm{CO}_{2}$ than usual under $\mathrm{CO}_{2}$-limited conditions [11]. Generally, the increase in LMA lengthens the internal diffusion pathway to chloroplasts, which decreases the $\mathrm{CO}_{2}$ supply, which in turn increases a stable isotope ratio $\left(\delta^{13} \mathrm{C}\right)$ [12] [13]. Therefore, LMA often positively correlates with $\delta^{13} \mathrm{C}$ [2] [14] [15] [16]. Deficiency of $\mathrm{CO}_{2}$ in leaves possibly occurs at high elevations if plants increase LMA to intensify the mechanical stiffness, which in turn reduces photosynthesis. Photosynthetic enzymes, such as RuBP carboxylase and leaf chlorophyll with light harvest ability, are nitrogen compounds. Generally, photosynthetic rate positively correlates with nitrogen content per leaf mass [17] [18]. If LMA and nitrogen content per leaf mass are high, the nitrogen content per leaf area increases, which increases the photosynthetic rate per leaf area by increasing the $\mathrm{CO}_{2}$ demand per leaf area [19] [20]. Therefore, it is possible that deciduous plant species maintain a positive carbon balance at the individual leaf level at high elevations if both LMA and nitrogen content per leaf mass are high at high elevations.

Deciduous broad-leaved tree species Betula ermanii Cham. is distributed widely in the subalpine zone in central Japan [21]. This study examined photosynthetic, leaf morphological and physiological traits of $B$. ermanii at three elevations to clarify the hypothesis that $B$. ermanii maintains a positive carbon balance at the individual leaf level at high elevations by increasing both LMA and nitrogen content per leaf mass.

\section{Study Site}

This study was done in the subalpine zone on the east slope of Mt. Norikura 
$\left(36^{\circ} 06^{\prime} \mathrm{N}, 137^{\circ} 33^{\prime} \mathrm{E}, 3026 \mathrm{~m}\right.$ above sea level) in central Japan. Mean monthly temperatures of the coldest month (January) and the hottest month (August) at $2000 \mathrm{~m}$ a.s.l. were estimated as $-9.2^{\circ} \mathrm{C}$ and $14.9^{\circ} \mathrm{C}$, respectively, with $2.7^{\circ} \mathrm{C}$ annual mean temperature, from temperatures recorded at Nagawa Weather Station (1068 m a.s.l.) during 1979-2011 using the standard lapse rate of $-0.6^{\circ} \mathrm{C}$ for each $+100 \mathrm{~m}$ elevation. The annual total precipitation was $2206 \mathrm{~mm}$ at Nagawa Weaterh Station.

The study site was dominated by conifers Abies mariesii Mast., A veitchii Lindl. and Tsuga diversifolia Mast. Although Picea jezoensis var. hondoensis Rehde also grows at this study site, the density was lower than for the three other species [22]. Subordinate trees were all deciduous broad-leaved trees: Betula ermanii Cham., Sorbus commixta Hedland and Acer ukurunduense Trantv. et Meyer. Miyajima et al. [22] and Miyajima and Takahashi [23] describe in detail the species composition and forest structure along an elevational gradient of $\mathrm{Mt}$. Norikura.

\section{Materials and Methods}

\subsection{Photosynthetic Measurements}

This study measured the photosynthesis and related leaf traits of B. ermanii. $B$. ermanii is a shade-intolerant deciduous broad-leaved tree species distributing in subalpine forests and often forms secondary forests after large scale disturbances, such as forest fire and scarification [24] [25]. Leaf emergence of B. ermanii is the succeeding type [26]. Early leaves unfold on short shoots in the beginning of the growing season, and then late leaves unfold sequentially with elongation of long shoots until August. The leaf primordium of early leaves is formed in the previous year of growth [27]. Early and late leaves have different phenology and photosynthetic characteristics [28]. Generally, photosynthetic rate decreases with leaf age [29] [30]. The photosynthetic rate of early leaves decreases earlier than late leaves [28]. Therefore, this study examined the photosynthesis and the leaf traits of $B$. ermanii only for late leaves.

Five trees ( $2-5 \mathrm{~m}$ tall) were selected at open sites at each of $1600 \mathrm{~m}, 2000 \mathrm{~m}$ and $2500 \mathrm{~m}$ a.s.l. in August 2013. Study sites at $1600 \mathrm{~m}, 2000 \mathrm{~m}$ and $2500 \mathrm{~m}$ a.s.l. are indicated as low, middle and high elevations, respectively, in this study. A sun-exposed branch was sampled from each tree and was brought back to the laboratory of Shinshu University at Matsumoto Campus (622 m a.s.l.). Branches were kept at a room temperature $18^{\circ} \mathrm{C}$ overnight. Photosynthesis was measured the next morning until noon (6:00 - 12:00) because photosynthesis and transpiration are more active in morning than in the afternoon [31] [32] [33]. Photosynthesis of $B$. ermanii was measured by using a portable photosynthesis system (model LI-6400, Li-Cor Biosciences, Lincoln, NE, USA) equipped with a chamber, including a light source (6400-02B). Incoming $\mathrm{CO}_{2}$ gas concentration from a $\mathrm{CO}_{2}$ cartridge was set at $380 \mathrm{ppm}$. The leaf temperature was maintained at $20^{\circ} \mathrm{C}$. The light-saturated maximum photosynthetic rate was measured at photosynthetic photon flux density (PPFD) $1000 \mu \mathrm{mol} \cdot \mathrm{m}^{-2} \cdot \mathrm{s}^{-1}$ [28] [34]. Photosyn- 
thesis was measured at least two leaves for each branch. Stomatal conductance and the ratio of $\mathrm{CO}_{2}$ partial pressure of intercellular airspace $\left(C_{i}\right)$ to that of ambient air $\left(C_{a}\right)$ were also recorded at the photosynthetic measurement. Photosynthetic nitrogen use efficiency (PNUE) was calculated by the photosynthetic rate divided by leaf nitrogen on the leaf area basis.

\subsection{Leaf Measurements}

Leaf chlorophyll was extracted using dimethylformamide $(4 \mathrm{ml})$. The absorbance of samples extracted from leaf samples at $663.8 \mathrm{~nm}\left(A^{663.8}\right)$ and $646.8 \mathrm{~nm}\left(A^{646.8}\right)$ was measured by using a spectrophotometer (UVmini-1240, Shimadzu, Kyoto), and was substituted into Porra's equations [35] to calculate chlorophyll $a$ and $b$ concentrations $\left(\mu \mathrm{g} \cdot \mathrm{ml}^{-1}\right)$.

$$
\begin{aligned}
& \text { Chl } a=12.00 A^{663.8}-3.11 A^{646.8} \\
& \text { Chl } b=20.78 A^{646.8}-4.88 A^{663.8}
\end{aligned}
$$

Leaves were scanned using free software ImageJ 1.47 (http://rsbweb.nih.gov/ij/index.html), the leaf area was measured, and the leaves were oven-dried at $80^{\circ} \mathrm{C}$ for 48 hours and were weighed. The LMA of each leaf was calculated by leaf dry mass divided by leaf area. After the measuring leaf dry mass, the leaves were ground into a fine powder, was oven-dried for 24 hours, and the nitrogen content per leaf mass and stable carbon isotope ratio $\left(\delta^{13} \mathrm{C}\right)$ were measured by using an isotope ratio mass spectrometer (DELTA plus, Thermo Electron Ltd., Yokohama, Japan) equipped with an elemental analyzer (FlashEA1112, Thermo Electron, Ltd., Yokohama, Japan).

\subsection{Statistical Analyses}

Tukey multiple comparison tests were used to compare the following leaf traits among the three elevations: LMA, leaf nitrogen and chlorophyll contents, chlorophyll/nitrogen ratio, chlorophyll $a / b$ ratio, $\delta^{13} \mathrm{C}, C_{i} / C_{a}$, stomatal conductance, photosynthetic rate and PNUE. Proportional data were transformed by squareroot-arcsine before the statistical analysis. Relationships between leaf $\delta^{13} \mathrm{C}$ and LMA and between stomatal conductance and leaf $\delta^{13} \mathrm{C}$ were analyzed by the regression analysis. All statistical analyses used free statistical software R 2.14.2 [36].

\section{Results}

\subsection{Leaf Structure}

LMA was greater at middle and high elevations than at low elevation (Tukey HSD test, $P<0.05$, Figure $1(\mathrm{a})$ ). Nitrogen contents per leaf mass and leaf area were greater at high elevation than at middle and low elevations (Tukey HSD test, $P<0.05$, Figure $1(\mathrm{~b})$, Figure $1(\mathrm{c})$ ). No statistical significant difference was detected among the three elevations for chlorophyll content per leaf area, chlorophyll/nitrogen ratio and chlorophyll $a / b$ ratio (Figures $1(\mathrm{~d})$-(f)). Therefore, LMA and the nitrogen content per leaf mass were high at high elevation, and ni- 
trogen allocation ratios to chlorophyll $a$ and $b$ showed no elevational differences.

\subsection{Gas Exchange}

The $\delta^{13} \mathrm{C}$ of leaves was less negative at higher elevations (Tukey HSD test, $P<0.05$,
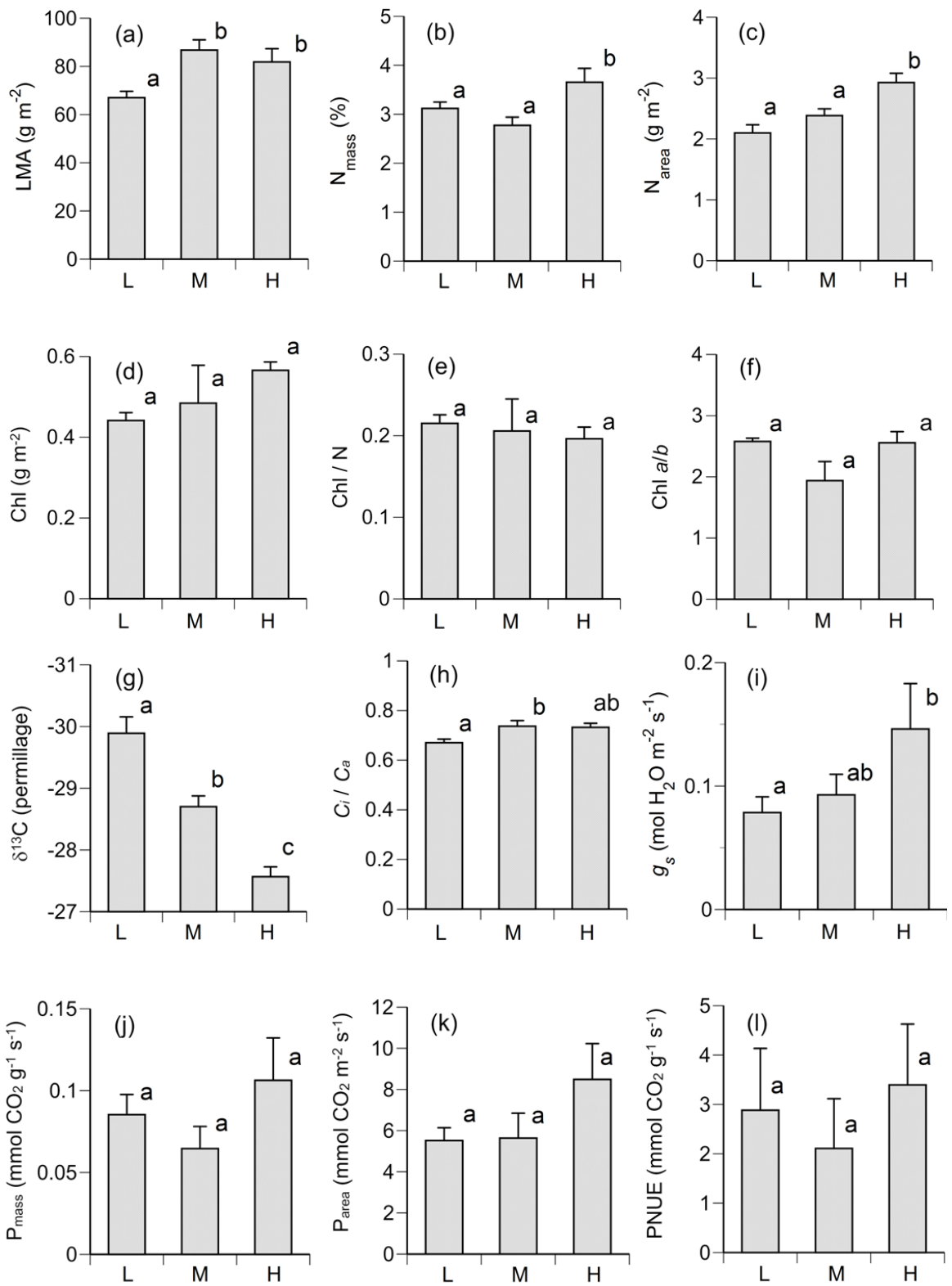

Figure 1. Leaf structural and physiological characteristics of Betula ermanii at low elevation (L, $1600 \mathrm{~m}$ a.s.l.), middle elevation (M, $2000 \mathrm{~m}$ a.s.l.) and high elevation (H, $2500 \mathrm{~m}$ a.s.l.). Mean values and standard errors are shown for (a) leaf mass per area (LMA), (b) nitrogen content per leaf mass $\left(\mathrm{N}_{\text {mass }}\right)$, (c) nitrogen content per leaf area $\left(\mathrm{N}_{\text {area }}\right)$, (d) chlorophyll content per leaf area $(\mathrm{Chl}),(e)$ ratio of chlorophyll to nitrogen $(\mathrm{Chl} / \mathrm{N}),(\mathrm{f}) \mathrm{Chl}$ $a / b$ ratio, (g) stable carbon isotope ratio $\left(\delta^{13} \mathrm{C}\right)$, (h) ratio of intercellular to the ambient $\mathrm{CO}_{2}$ partial pressure $\left(C_{i} / C_{a}\right)$, (i) stomatal conductance $\left(g_{s}\right)$, (j) photosynthetic rate per leaf mass $\left(\mathrm{P}_{\text {mass }}\right),(\mathrm{k})$ photosynthetic rate per leaf area $\left(\mathrm{P}_{\text {area }}\right)$, and $(\mathrm{l})$ photosynthetic nitrogen use efficiency (PNUE). Stomatal conductance and photosynthetic rates were measured at photosynthetic photon flux density $1000 \mu \mathrm{mol} \cdot \mathrm{m}^{-2} \cdot \mathrm{s}^{-1}$. Same letters indicate no significant difference at the level of 0.05 by the Tukey HSD test in each graph. 
Figure $1(\mathrm{~g}))$ and it positively correlated with LMA $\left(R^{2}=0.224, P<0.01\right.$, Figure 2). On the contrary, the $C_{i} / C_{a}$ ratio at high elevation did not differ from this ratio at low and middle elevations (Figure $1(\mathrm{~h})$ ).

Stomatal conductance tended to be greater at higher elevations (Tukey HSD test, $P<0.05$, Figure 1(i)). A positive correlation was found between $\delta^{13} \mathrm{C}$ and stomatal conductance $\left(R^{2}=0.149, P<0.05\right.$, Figure 3$)$. The photosynthetic rate per leaf area showed a high positive correlation with stomatal conductance $\left(R^{2}=\right.$ $0.830, P<0.001$, Figure 4). Photosynthetic rates per leaf mass and per leaf area (Figure 1(j), Figure 1(k)), and PNUE (Figure 1(1)), showed no statistical significant difference among the three elevations. Therefore, the photosynthetic rate and PNUE were maintained at high elevation as much as at low and middle elevations.

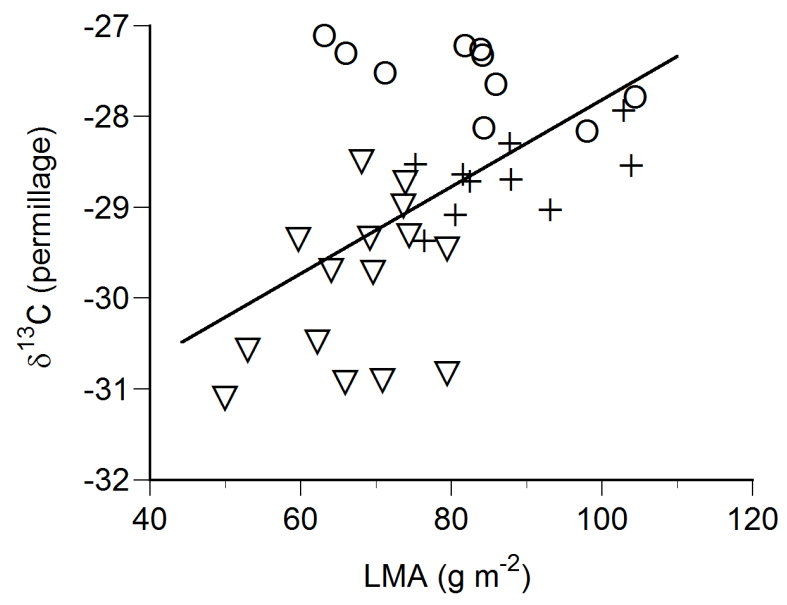

Figure 2. Relationship between leaf mass per area (LMA) and stable carbon isotope ratio $\left(\delta^{13} \mathrm{C}\right)$ for Betula ermanii leaves from low elevation (1600 $\mathrm{m}$ a.s.l., triangle), middle elevation (2000 m a.s.l., cross) and high elevation (2500 $\mathrm{m}$ a.s.l., circle). The regression line is $Y$ $=0.043 X-32.19\left(F_{1,33}=10.8, P<0.01, R^{2}=0.224\right)$ for pooled data of the three elevations.

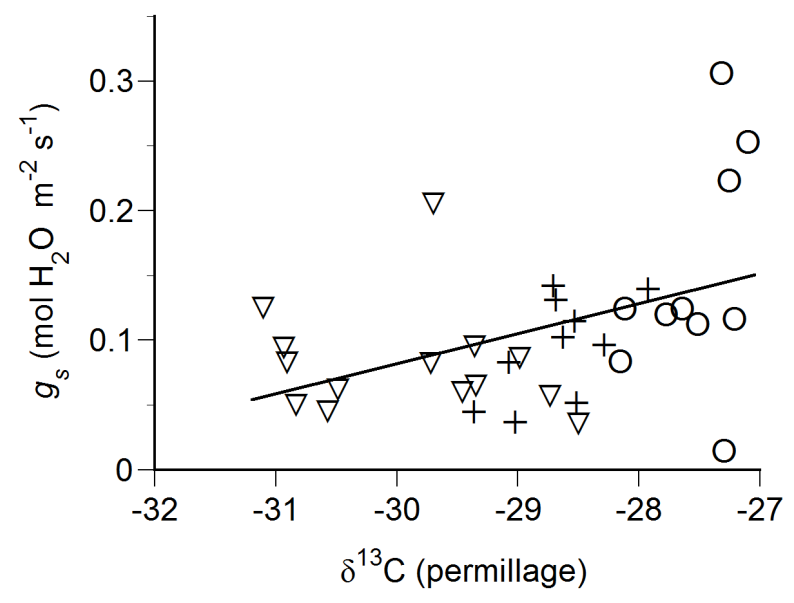

Figure 3. Relationship between stable carbon isotope ratio $\left(\delta^{13} \mathrm{C}\right)$ and stomatal conductance $\left(g_{s}\right)$ for Betula ermanii leaves from low elevation (1600 m a.s.l., triangle), middle elevation (2000 $\mathrm{m}$ a.s.l., cross) and high elevation (2500 $\mathrm{m}$ a.s.l., circle). The regression line is $Y=0.0225 X+0.752\left(F_{1,33}=6.95, P<0.05, R^{2}=0.149\right)$ for pooled data of the three elevations. 


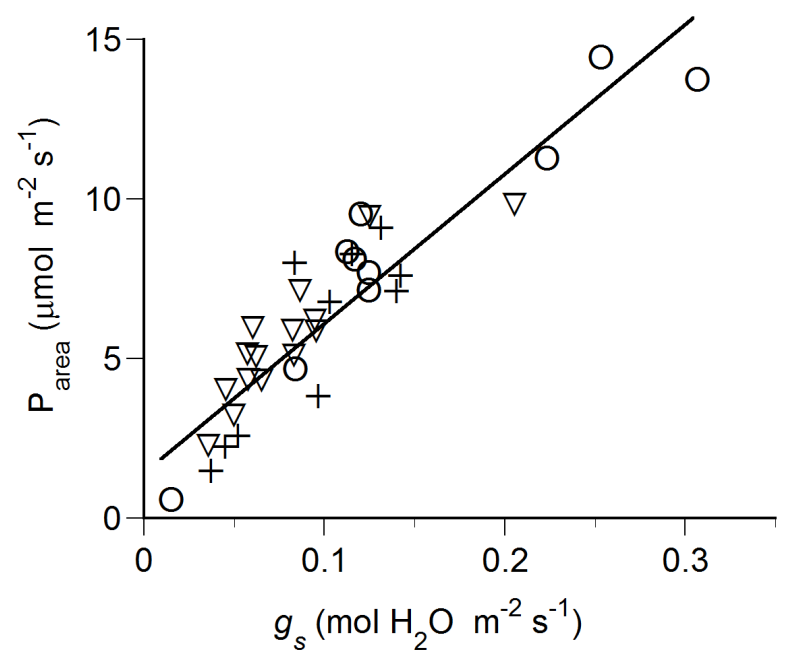

Figure 4. Relationship between stomatal conductance $\left(g_{s}\right)$ and photosynthetic rate per leaf area $\left(\mathrm{P}_{\text {area }}\right)$ at photosynthetic photon flux density $1000 \mu \mathrm{mol} \cdot \mathrm{m}^{-2} \cdot \mathrm{s}^{-1}$ for Betula ermanii leaves from low elevation (1600 m a.s.l., triangle), middle elevation (2000 m a.s.l., cross) and high elevation (2500 $\mathrm{m}$ a.s.l., circle). The regression line is $Y=46.23 X+1.688\left(F_{1,33}=\right.$ 167.4, $P<0.001, R^{2}=0.830$ ) for pooled data of the three elevations.

\section{Discussion}

The LMA of $B$. ermanii was greater at middle and high elevations than at low elevation, and positively correlated with $\delta^{33} \mathrm{C} . \mathrm{CO}_{2}$ is suggested to be deficient in leaves with high LMA because of the long internal diffusion pathway to chloroplasts from stomata. Therefore, the photosynthetic rate was expected to be low at high elevation because of the $\mathrm{CO}_{2}$ deficiency in leaves due to high LMA. However, no reduction was observed in the $C_{i} / C_{a}$ ratio at photosynthetic measurement of leaves at high elevation. The nitrogen content per leaf mass also increased at high elevation. The high nitrogen content per leaf mass indicates an increase in photosynthetic enzymes, such as RuBP carboxylase [18]. The $\mathrm{CO}_{2}$ demand increases for leaves with greater leaf nitrogen because of greater activity of photosynthesis. In fact, the stomatal conductance was high for leaves at high elevation; stomatal conductance and photosynthetic rate showed a high positive correlation on a leaf area basis. The stomatal conductance also positively correlated with $\delta^{13} \mathrm{C}$. These results indicate that $\mathrm{CO}_{2}$-deficient leaves with high LMA at high elevation increased the stomatal conductance. Therefore, this study suggests that $B$. ermanii maintains a positive carbon balance at the individual leaf level at high elevations by increasing the nitrogen content per leaf mass and stomatal conductance, even if $B$. ermanii intensifies the mechanical stiffness of leaves (i.e., LMA), which supports the hypothesis.

The LMA increases in many plant species at high elevations [12] [20] [37] [38] [39] [40]. The increase in mechanical stiffness (i.e., LMA) at high elevations is thought to be an adaptation to strong wind, low temperature and UV-B [8] [38] [41] [42]. Although many studies have examined elevational differences of photosynthetic rates, their results are not consistent, i.e., an increase [43] [44], a decrease [45] [46] [47] [48] or no tendency [49] [50] in photosynthetic rates at 
high elevations. Generally, leaf nitrogen content positively correlates with photosynthetic rate at light saturation [3] [4] [5]. However, some studies showed that photosynthetic rates per leaf area do not increase even if the nitrogen content per leaf area increases [46] [47]. Therefore, the change in leaf nitrogen contents is suggested to be not a causal factor for elevational differences in photosynthetic rates. The LMA was greater and $\delta^{13} \mathrm{C}$ was less negative at higher elevations in these previous studies [46] [47]. Increase in LMA lengthens the internal diffusion pathway to chloroplasts, which decreases the $\mathrm{CO}_{2}$ supply. Therefore, the long-term $C_{i} / C_{a}$ ratio decreases and discrimination between ${ }^{12} \mathrm{CO}_{2}$ and ${ }^{13} \mathrm{CO}_{2}$ becomes less as the $\mathrm{CO}_{2}$ supply decreases, which in turn increases the $\delta^{13} \mathrm{C}$ of leaves [2] [12] [13] [16]. Thus, elevational change in $\delta^{13} \mathrm{C}$ is suggested to be strongly regulated by the elevational change in LMA. Often reported is that photosynthetic rate positively correlates with stomatal conductance [19] [51] [52], and elevational changes in photosynthetic rates also tend to be in accordance with elevational changes in stomatal conductance [46] [49].

Plants not only absorb $\mathrm{CO}_{2}$ by opening stomata, but also emit water through stomata (i.e., transpiration) simultaneously. Plants close stomata to prevent transpiration in response to drought of the atmosphere and soil [53] [54] [55] [56]. Conversely, stomatal conductance is an indicator of the ability of soil water acquisition [57] [58]. In situ stomatal conductance of B. ermanii on Mt. Noriku$\mathrm{ra}$ is greater and pre-dawn water potential of leaves is also less negative at higher elevations [2]. Greater stomatal conductance of B. ermanii at higher elevations indicates more opening of stomata because the stomatal density of $B$. ermanii does not differ along an elevational gradient [2]. Greater stomatal conductance of B. ermanii at high elevations is thought to be due to less drought stress because precipitation is greater at higher elevations in the region of the study site [59]. On the contrary, radiation energy on fine days is greater at higher elevations [60]. Shade-intolerant B. ermanii may be able to utilize high radiation energy effectively for photosynthesis by having high stomatal conductance, which contributes to annual photosynthetic production.

Plant species with short leaf longevity are thought to maintain a positive carbon balance at the individual leaf level by producing leaves with low LMA and high photosynthetic rates [61]. However, although LMA of $B$. ermanii at high elevation was high in this study, $B$. ermanii could maintain the photosynthetic rate as much as at low elevation by increasing stomatal conductance. Namely, the results of this study cannot be explained by the conventional theory of leaf longevity. This study provides a new finding of elevational differences in leaf longevity, photosynthesis, morphological and physiological traits of leaves. However, further studies are necessary to show elevational patterns in photosynthesis and related leaf traits of other plant species for understanding of the adaptation of plants at the individual leaf level to high elevations.

\section{Acknowledgements}

We are grateful to Prof. $\mathrm{H}$. Toda for support of the $\delta^{13} \mathrm{C}$ analysis. This study was 
partially supported by grants from the Ministry of Education, Culture, Sports, Science and Technology, Japan.

\section{References}

[1] Kudo, G. (1995) Altitudinal Effects on Leaf Traits and Shoot Growth of Betula platyphylla var. japonica. Canadian Journal of Forest Research, 25, 1881-1885. https://doi.org/10.1139/x95-203

[2] Takahashi, K. and Miyajima, Y. (2008) Relationship among Leaf Life Span, Leaf Mass per Area and Leaf Nitrogen Causes Different Altitudinal Changes in Leaf $\delta^{13} \mathrm{C}$ between Deciduous and Evergreen Species. Botany, 86, 1233-1241. https://doi.org/10.1139/B08-093

[3] Reich, P.B., Uhl, C., Walters, M.B. and Ellsworth, D.S. (1991) Leaf Lifespan as a Determinant of Leaf Structure and Function among 23 Amazonian Tree Species. Oecologia, 86, 16-24. https://doi.org/10.1007/BF00317383

[4] Reich, P.B., Walters, M.B. and Ellsworth, D.S. (1992) Leaf Life-Span in Relation to Leaf, Plant, and Stand Characteristics among Diverse Ecosystems. Ecological Monographs, 62, 365-392. https://doi.org/10.2307/2937116

[5] Wright, I.J., Reich, P., Westoby, M., Ackerly, D.D., Baruch, Z., Bongers, F., Cavender-Bares, J., Chapin, T., Cornelissen, J.H.C., Diemer, M., Flexas, J., Garnier, E., Groom, P.K., Gulias, J., Hikosaka, K., Lamont, B.B., Lee, T., Lee, W., Lusk, C., Midgley, J.J., Navas, M.L., Niinemets, Ü., Oleksyn, J., Osada, N., Poorter, H., Poot, P., Prior, L., Pyankov, V.I., Roumet, C., Thomas, S.C., Tjoelker, M.G., Veneklaas, E.J. and Villar, R. (2004) The Worldwide Leaf Economics Spectrum. Nature, 428, 821-827. https://doi.org/10.1038/nature02403

[6] Körner, C. (1999) Alpine Plant Life. Springer, Berlin. https://doi.org/10.1007/978-3-642-98018-3

[7] Kudo, G. (1999) A Review of Ecological Studies on Leaf-Trait Variations along Environmental Gradients-In the Case of Tundra Plants. Japanese Journal of Ecology, 49, 21-35. (In Japanese)

[8] Woodward, F.I. (1983) The Significance of Interspecific Differences in Specific Leaf Area to the Growth of selected Herbaceous Species from Different Altitudes. New Phytologist, 95, 313-323. https://doi.org/10.1111/j.1469-8137.1983.tb03498.x

[9] Premoli, A.C. and Brewer, C.A. (2007) Environmental v. Genetically Driven Variation in Ecophysiological Traits of Nothofagus pumilio from Contrasting Elevations. Australian Journal of Botany, 55, 585-591. https://doi.org/10.1071/BT06026

[10] Bresson, C.C. and Kowalski, A.S. (2009) Evidence of Altitudinal Increase in Photosynthetic Capacity: Gas Exchange Measurements at Ambient and Constant $\mathrm{CO}_{2}$ Partial Pressures. Annals of Forest Science, 66, 505-512.

https://doi.org/10.1051/forest/2009027

[11] Farquhar, G.D., Ball, M.C., von Caemmerer, S. and Roksandic, Z. (1982) Effect of Salinity and Humidity on $\delta^{13} \mathrm{C}$ Value of Halophytes-Evidence for Diffusional Isotope Fractionation Determined by the Ratio of Intercellular/Atmospheric Partial Pressure of $\mathrm{CO}_{2}$ under Different Environmental Conditions. Oecologia, 52, 121 124. https://doi.org/10.1007/BF00349020

[12] Sparks, J.P. and Ehleringer, J.R. (1997) Leaf Carbon Isotope Discrimination and Nitrogen Content for Riparian Trees along Elevational Transects. Oecologia, 109, 362-367. https://doi.org/10.1007/s004420050094

[13] Niinemets, Ü., Kull, O. and Tenhunen, J.D. (1999) Variability in Leaf Morphology and Chemical Composition as a Function of Canopy Light Environment in Coex- 
isting Deciduous Trees. International Journal of Plant Sciences, 160, 837-848. https://doi.org/10.1086/314180

[14] Vitousek, P.M., Field, C.B. and Matson, P.A. (1990) Variation in foliar $\delta^{13} \mathrm{C}$ in Hawaiian Metrosideros polymorpha: A Case of Internal Resistance? Oecologia, 84, 362-370. https://doi.org/10.1007/BF00329760

[15] Hultine, K.R. and Marshall, J.D. (2000) Altitude Trends in Conifer Leaf Morphology and Stable Carbon Isotope Composition. Oecologia, 123, 32-40. https://doi.org/10.1007/s004420050986

[16] Takahashi, K. and Mikami, Y. (2006) Effects of Canopy Cover and Seasonal Reduction in Rainfall on Leaf Phenology and Leaf Traits of the Fern Oleandra pistillaris in a Tropical Montane Forest, Indonesia. Journal of Tropical Ecology, 22, 599-604. https://doi.org/10.1017/S0266467406003531

[17] Field, C. and Mooney, H.A. (1983) Leaf Age and Seasonal Effects on Light, Water and Nitrogen Use Efficiency in a California Shrub. Oecologia, 56, 348-355. https://doi.org/10.1007/BF00379711

[18] Evans, J.R. (1989) Photosynthesis and Nitrogen Relationships in Leaves of $\mathrm{C}_{3}$ Plants. Oecologia, 78, 9-19. https://doi.org/10.1007/BF00377192

[19] Wong, S.C., Cowan, I.R. and Farquhar, G.D. (1985) Leaf Conductance in Relation to Rate of $\mathrm{CO}_{2}$ Assimilation. Plant Physiology, 78, 821-825. https://doi.org/10.1104/pp.78.4.821

[20] Körner, C., Bannister, P. and Mark, A.F. (1986) Altitudinal Variation in Stomatal Conductance, Nitrogen Content and Leaf Anatomy in Different Plant Life Forms in New Zealand. Oecologia, 69, 577-588. https://doi.org/10.1007/BF00410366

[21] Miyawaki, A. (1985) Vegetation of Japan 6, Chubu. Shibundo, Tokyo. (In Japanese)

[22] Miyajima, Y., Sato, T. and Takahashi, K. (2007) Altitudinal Changes in Vegetation of Tree, Herb and Fern Species on Mount Norikura, Central Japan. Vegetation Science, 24, 29-40.

[23] Miyajima, Y. and Takahashi, K. (2007) Changes with Altitude of the Stand Structure of Temperate Forests on Mount Norikura, Central Japan. Journal of Forest Research, 12, 187-192. https://doi.org/10.1007/s10310-007-0002-3

[24] Kikuzawa, K. (1988) Intraspecific Competition in a Natural Stand of Betula ermanii. Annals of Botany, 61, 727-734.

[25] Takahashi, K., Uemura, S., Suzuki, J. and Hara, T. (2003) Effects of Understory Dwarf Bamboo on Soil Water and Growth of Overstory Trees in a Dense Secondary Betula ermanii Forest, Northern Japan. Ecological Research, 18, 767-774. https://doi.org/10.1007/s11284-003-0594-9

[26] Kikuzawa, K. (1983) Leaf Survival of Woody Plants in Deciduous Broad-Leaved Forests. 1. Tall Trees. Canadian Journal of Botany, 61, 2133-2139. https://doi.org/10.1139/b83-230

[27] Kikuzawa, K. (1982) Leaf Survival and Evolution in Betulaceae. Annals of Botany, 50, 345-353.

[28] Miyazawa, Y. and Kikuzawa, K. (2004) Phenology and Photosynthetic Traits of Short Shoots and Long Shoots in Betula grossa. Tree Physiology, 24, 631-637. https://doi.org/10.1093/treephys/24.6.631

[29] Sestak, A., Ticha, I., Catky, J., Solarova, J., Pospisilova, J. and Hodanova, D. (1985) Integration of Photosynthetic Characteristics during Leaf Development. In: Sestak, A., Ed., Photosynthetic during Leaf Development, Junk, Dordrecht, 263-286. https://doi.org/10.1007/978-94-009-5530-1 11 
[30] Kitajima, K., Mulkey, S.S. and Wright, S.J. (1997) Decline of Photosynthetic Capacity with Leaf Age in Relation to Leaf Longevities for Five Tropical Canopy Tree Species. American Journal of Botany, 84, 702-708. https://doi.org/10.2307/2445906

[31] Dang, Q.L., Lieffers, V.J., Rothwell, R.L. and Macdonald, S.E. (1991) Diurnal Variation and Interrelations of Ecophysiological Parameters in Three Peatland Woody Species under Different Weather and Soil Moisture Conditions. Oecologia, 88, 317-324. https://doi.org/10.1007/BF00317573

[32] Bassow, S.L. and Bazzaz, F.A. (1998) How Environmental Conditions Affect Canopy Leaf-Level Photosynthesis in Four Deciduous Tree Species. Ecology, 79, 2660 2675. https://doi.org/10.1890/0012-9658(1998)079[2660:HECACL]2.0.CO;2

[33] Takahashi, K. (2003) Diurnal Variations in Stomatal Conductance of Betula ermanii and Pinus pumila at the Timberline on Mt. Shogigashira, Central Japan. Journal of Phytogeography and Taxonomy, 51, 159-164.

[34] Takahashi, K., Matsuki, S., Uemura, S. and Hara, T. (2004) Variations in the Maximum Photosynthetic Rate of Betula ermanii in Relation to Soil Water Potential. Vegetation Science, 21, 103-108.

[35] Porra, R.J., Thompson, W.A. and Kriedemann, P.E. (1989) Determination of Accurate Extinction Coefficients and Simultaneous Equations for Assaying Chlorophylls $a$ and $b$ Extracted with Four Different Solvents: Verification of the Concentration of Chlorophyll Standards by Atomic Absorption Spectroscopy. Biochimica et Biophysica Acta, 975, 384-394. https://doi.org/10.1016/S0005-2728(89)80347-0

[36] R Development Core Team (2012) R: A Language and Environment for Statistical Computing. R Foundation for Statistical Computing, Vienna, Austria. http://www.R-project.org

[37] Körner, C., Farquhar, G.D. and Roksandic, Z. (1988) A Global Survey of Carbon Isotope Discrimination in Plants from High Altitude. Oecologia, 74, 623-632. https://doi.org/10.1007/BF00380063

[38] Körner, C., Neumayer, M., Menendez-Riedl, S.P. and Smeets-Scheel, A. (1989) Functional Morphology of Mountain Plants. Flora, 182, 353-383.

[39] Castrillo, M. and Simoes, M. (1997) Leaf Non-Structural Cabohydrates and Leaf Dry Weight per Area in Three Altitudinal Populations of Espeletia schultzii Weed. Folia Geobotanica Phytotaxonomica, 32, 355-360. https://doi.org/10.1007/BF02821941

[40] Li, C., Zhang, X., Liu, X., Luukkanen, O. and Berninger, F. (2006) Leaf Morphological and Physiological Responses of Quercus aquifolioides along an Altitudinal Gradient. Silva Fennica, 40, 5-13. https://doi.org/10.14214/sf.348

[41] Coley, P.D. (1983) Herbivory and Defensive Characteristics of Tree Species in a Lowland Tropical Forest. Ecological Monographs, 53, 209-235. https://doi.org/10.2307/1942495

[42] Wardlaw, I.F., Begg, J.E., Bagnall, D. and Dunstone, R.L. (1983) Jojoba: Temperature Adaptation as Expressed in Growth and Leaf Function. Australian Journal of Plant Physiology, 10, 299-312. https://doi.org/10.1071/PP9830299

[43] Ledig, F.T. and Korbobo, D.R. (1983) Adaptation of Sugar Maple Populations along Altitudinal Gradients: Photosynthesis, Respiration, and Specific Leaf Weight. American Journal of Botany, 70, 256-265. https://doi.org/10.2307/2443271

[44] Oleksyn, J., Modrzynski, J., Tjoelker, M.G., Zytkowiak, R., Reich, P.B. and Karolewski, P. (1998) Growth and Physiology of Picea abies Populations from Elevational Transects: Common Garden Evidence for Altitudinal Ecotypes and Cold Adaptation. Functional Ecology, 12, 573-590. 
https://doi.org/10.1046/j.1365-2435.1998.00236.x

[45] Cabrera, H.M., Rada, F. and Cavieres, L. (1998) Effects of Temperature on Photosynthesis of Two Morphologically Contrasting Plant Species along an Altitudinal Gradient in the Tropical High Andes. Oecologia, 114, 145-152. https://doi.org/10.1007/s004420050430

[46] Kogami, H., Hanba, Y.T., Kibe, T., Terashima, I. and Masuzawa, T. (2001) $\mathrm{CO}_{2}$ Transfer Conductance, Leaf Structure and Carbon Isotope Composition of Polygonum cuspidatum Leaves from Low and High Altitudes. Plant, Cell and Environment, 24, 529-538. https://doi.org/10.1046/j.1365-3040.2001.00696.x

[47] Hikosaka, K., Nagamatsu, D., Ishii, H.S. and Hirose, T. (2002) Photosynthesis-Nitrogen Relationships in Species at Different Altitudes on Mount Kinabalu, Malaysia. Ecological Research, 17, 305-313.

https://doi.org/10.1046/j.1440-1703.2002.00490.x

[48] Richardson, A.D. and Berlyn, G.P. (2002) Spectral Reflectance and Photosynthetic Properties of Betula papyrifera (Betulaceae) Leaves along an Elevational Gradient on Mt. Mansfield, Vermont, USA. American Journal of Botany, 89, 88-94.

https://doi.org/10.3732/ajb.89.1.88

[49] Cordell, S., Goldstein, G., Mueller-Dombois, D., Webb, D. and Vitousek, P.M. (1998) Physiological and Morphological Variation in Metrosideros polymorpha, a Dominant Hawaiian Tree Species, along an Altitudinal Gradient: The Role of Phenotypic Plasticity. Oecologia, 113, 188-196. https://doi.org/10.1007/s004420050367

[50] Piper, F.I., Cavieres, L.A., Reyes-Díaz, M. and Corcuera, L.J. (2006) Carbon Sink Limitation and Frost Tolerance Control Performance of the Tree Kageneckia angustifolia D. Don (Rosaceae) at the Treeline in Central Chile. Plant Ecology, 185, 29-39. https://doi.org/10.1007/s11258-005-9081-4

[51] Wong, S.C., Cowan, I.R. and Farquhar, G.D. (1979) Stomatal Conductance Correlates with Photosynthetic Capacity. Nature, 282, 424-426. https://doi.org/10.1038/282424a0

[52] Friend, A.D., Woodward, F.I. and Switsur, V.R. (1989) Field Measurements of Photosynthesis, Stomatal Conductance, Leaf Nitrogen and $\delta^{13} \mathrm{C}$ along Altitudinal Gradients in Scotland. Functional Ecology, 3, 117-122. https://doi.org/10.2307/2389682

[53] Bréda, N., Granier, A., Barataud, F. and Moyne, C. (1995) Soil Water Dynamics in an Oak Stand. Plant and Soil, 172, 17-27. https://doi.org/10.1007/BF00020856

[54] Granier, A. and Bréda, N. (1996) Modelling Canopy Conductance and Stand Transpiration of an Oak Forest from Sap Flow Measurements. Annals des Sciences Forestieres, 53, 537-546. https://doi.org/10.1051/forest:19960233

[55] Cienciala, E., Kucera, J., Ryan, M.G. and Lindroth, A. (1998) Water Flux in Boreal Forest during Two Hydrologically Contrasting Years. Species Specific Regulation of Canopy Conductance and Transpiration. Annals des Sciences Forestieres, 55, 47-61. https://doi.org/10.1051/forest:19980104

[56] Oren, R., Ewers, B.E., Todd, P., Phillips, N. and Katul, G. (1998) Water Balance Delineates the Soil Layer in Which Moisture Affects Canopy Conductance. Ecological Applications, 8, 990-1002. https://doi.org/10.1890/1051-0761(1998)008[0990:WBDTSL]2.0.CO;2

[57] Oberbauer, S.F. and Billings, W.D. (1981) Drought Tolerance and Water-Use by Plants along an Alpine Topographic Gradient. Oecologia, 50, 325-331. https://doi.org/10.1007/BF00344971

[58] Ehleringer, J.R. and Marshall, J.D. (1995) Water Relations. In: Press, M.C. and Graves, J.D., Eds., Parasitic Plants, Chapman and Hall, London, 1-13. 
[59] Nagano Meteorological Observatory (1998) Annual Report on Weather Conditions of Nagano Prefecture in 1998. Nagano Branch Office of Japanese Meteorological Society, Nagano. (In Japanese)

[60] Blumthaler, M. (2012) Solar Radiation of the High Alps. In: Lutz, C., Ed., Plants in Alpine Regions-Cell Physiology of Adaptation and Survival Strategies, Springer, Wien, 11-20. https://doi.org/10.1007/978-3-7091-0136-0 2

[61] Kikuzawa, K. (1991) A Cost-Benefit Analysis of Leaf Habit and Leaf Longevity of Trees and Their Geographical Pattern. American Naturalist, 138, 1250-1263. https://doi.org/10.1086/285281

Submit or recommend next manuscript to SCIRP and we will provide best service for you:

Accepting pre-submission inquiries through Email, Facebook, LinkedIn, Twitter, etc. A wide selection of journals (inclusive of 9 subjects, more than 200 journals) Providing 24-hour high-quality service User-friendly online submission system Fair and swift peer-review system Efficient typesetting and proofreading procedure Display of the result of downloads and visits, as well as the number of cited articles Maximum dissemination of your research work

Submit your manuscript at: http://papersubmission.scirp.org/

Or contactajps@scirp.org 